\title{
Meta-analysis of the impact of thioprine $S$-methyltransferase polymorphisms on the tolerable 6-mercaptopurine dose considering initial dose and ethnic difference
}

\author{
This article was published in the following Dove Press journal: \\ OncoTargets and Therapy \\ 18 November 2016 \\ Number of times this article has been viewed
}

\section{Myeong Gyu Kim \\ Minoh Ko \\ In-Wha Kim \\ Jung $\mathrm{MiOh}$}

College of Pharmacy and Research Institute of Pharmaceutical

Sciences, Seoul National University, Seoul, Korea
Correspondence: Jung Mi Oh College of Pharmacy and Research Institute of Pharmaceutical Sciences, Seoul National University, I Gwanak-ro, Gwanak-gu, Seoul I5I-742, Korea

Tel +8228807997

Fax +8228809560

Email jmoh@snu.ac.kr
Abstract: A meta-analysis was conducted to decide whether to reduce an initial 6-mercaptopurine (6-MP) dose in TPMT heterozygote in the case of an initial 6-MP dose of $<75 \mathrm{mg} / \mathrm{m}^{2} / \mathrm{d}$ and to compare the tolerable 6-MP dose among different ethnic groups. The study was undertaken according to Preferred Reporting Items for Systematic Reviews and Meta-Analyses guidelines. The differences in mean values of the tolerable 6-MP dose were calculated by using Comprehensive Meta-Analysis version 3. The results of the meta-analysis indicated that the tolerable 6-MP dose was significantly lower in the TPMT heterozygote group (difference in mean values $=11.729,95 \%$ confidence interval $=7.617-15.842, P<0.001)$ even when the initial $6-\mathrm{MP}$ dose was $<75 \mathrm{mg} / \mathrm{m}^{2} / \mathrm{d}$. The TPMT*3C allele-dominant ethnic group (Asian) needed less reduction in mean 6-MP dose in comparison to the TPMT*3A allele-dominant ethnic group (Caucasian, Mediterranean, South American) (difference in mean values $=8.884$ vs 15.324$)$. In conclusion, the initial 6-MP dose needs to be reduced in TPMT heterozygote when compared to the wild-type, and ethnic difference might influence the tolerable 6-MP dose in TPMT heterozygotes.

Keywords: 6-mercaptopurine, thiopurine $S$-methyltransferase, polymorphism, meta-analysis

\section{Introduction}

6-Mercaptopurine (6-MP) with methotrexate constitutes the mainstream of the maintenance therapy for acute lymphocytic leukemia (ALL), which is a prevalent hematologic disease seen in those under 20 years of age. ${ }^{1}$ To exhibit its cytotoxicity, 6-MP must be converted to its active metabolite, 6-thioguanine nucleotide, by multiple enzymes such as hypoxanthine-guanine phosphoribosyltransferase, inosine- $5^{\prime}$-monophosphate dehydrogenase, and guanine monophosphate synthetase. The drug is inactivated into 6-methylmercaptopurine through $S$-methylation by a polymorphic enzyme named thiopurine $S$-methyltransferase (TPMT). Thus, TPMT enzyme deficiency results in increased 6-thioguanine nucleotide and hematologic toxicity.

Presently, more than 20 mutant alleles have been reported, and it is known that $T_{P M T}^{*} 2, * 3 A$, and $* 3 C$ account for approximately $90 \%$ of the total mutant alleles. ${ }^{2}$ The Clinical Pharmacogenetics Implementation Consortium (CPIC) proposed a dosing recommendation according to TPMT genotypes. According to the recommendation, a homozygous wild-type starts 6-MP with a normal dose, the heterozygote starts as $30 \%-70 \%$ of the full dose $\left(50 \mathrm{mg} / \mathrm{m}^{2} / \mathrm{d}\right)$, and the homozygous variant starts with an extremely reduced dose. ${ }^{3,4}$ However, in most of Europe and Asia, the initial dose of 
6-MP is $50 \mathrm{mg} / \mathrm{m}^{2} / \mathrm{d} .{ }^{5}$ Under this condition, it is questionable whether a 6-MP dose should further be reduced.

A reduction in 6-MP dose is recommended for TPMT heterozygotes because an increased risk of hematologic toxicity was observed in comparison to those with wildtype TPMT in many American and European studies. ${ }^{6-12}$ However, TPMT enzyme activity differs between mutant alleles. The TPMT*3A (460G $>$ A, 719A $>$ G) allele, which is a major mutant allele in Caucasian, Mediterranean, South American, Middle Eastern, and Mexican origins, results in negligible activity, while the $T P M T^{*} 3 C(719 \mathrm{~A}>\mathrm{G})$ allele, which is a major allele in Asian and African origins, causes moderate activity compared to the wild-type one. ${ }^{13}$ Furthermore, Asians have another important variant, NUDT15, which is strongly associated with tolerable 6-MP dose according to a state-of-the-art genome-wide association study. ${ }^{14}$ Thus, 6-MP maintenance therapy according to TPMT genotype, which reflects ethnic allele distribution, needs to be evaluated. Although a number of Asian studies have evaluated the relationship between TPMT genotypes and tolerable 6-MP dose, the results are still controversial. For example, heterozygotes received less 6-MP dose in comparison to those with wild-type allele (32.1 vs $\left.46.2 \mathrm{mg} / \mathrm{m}^{2} / \mathrm{d}, P=0.05\right)$. One Indian study concluded that the identification of TPMT genotype might be important. ${ }^{15}$ On the other hand, the heterozygotes received a similar 6-MP dose (41.5 vs $42.92 \mathrm{mg} / \mathrm{m}^{2} / \mathrm{d}$ ) in another Indian study, and the study concluded that the identification of TPMT genotype might not be important. ${ }^{16}$

Evidence for individual study was weak because the number of TPMT heterozygotes was $\leq 12$, whereas a metaanalysis of these studies could increase the number of TPMT heterozygotes and strengthen the evidence.

The primary objective of this study was to decide whether to reduce an initial 6-MP dose in TPMT heterozygote when the maintenance regimen included a 6-MP dose of $<75 \mathrm{mg} / \mathrm{m}^{2} / \mathrm{d}$. The secondary objective was to compare the tolerable 6-MP dose between TPMT heterozygotes and those with wild-type allele among different ethnic groups.

\section{Materials and methods}

\section{Search strategy}

The meta-analysis process was predetermined prior to the study and conducted according to the checklist in the Preferred Reporting Items for Systematic Reviews and MetaAnalyses guidelines. ${ }^{17}$ For this study, we searched PubMed, Embase, and Cochrane Library Databases for studies that were conducted on childhood ALL patients using 6-MP so as to identify the impact of TPMT polymorphism on tolerable
6-MP dose. The latest search was updated on January 20, 2016. The following keywords were employed: (leukemia) AND (TPMT OR thiopurine methyltransferase OR thiopurine s methyltransferase OR thiopurine s-methyltransferase) AND (6-MP OR 6-mercaptopurine OR mercaptopurine) AND (polymorphism OR variant OR variation OR mutant OR mutation OR genotype OR haplotype). There were no limitations in the search process. To reduce publication bias, unpublished trials were searched via conference abstracts and trial registries such as the World Health Organization's International Clinical Trials Registry Platform Search Portal (www.who.int/trialsearch/) and ClinicalTrials.gov. ${ }^{18}$

\section{Study selection}

Two authors of this study independently evaluated all papers for eligibility. The criteria for eligibility for this study should 1) involve childhood ALL patients treated with 6-MP as a part of a maintenance therapy, 2) have an initial 6-MP dose of $<75 \mathrm{mg} / \mathrm{m}^{2} / \mathrm{d}, 3$ ) analyze TPMT genotypes in the patients, and 4) compare tolerable 6-MP dose information according to the status of TPMT genotypes.

Articles were excluded if the research 1) was not carried on human subjects, 2) just evaluated the effects of TPMT phenotypes, and 3 ) did not report tolerable doses (pharmacokinetic outcomes or clinical outcomes). Reviews, guidelines, letters, comments, and case reports were also excluded.

EndNote X7.2 (Thomson Reuters, New York, NY, USA; 2014) software was used in the citation process. Cohen's $\kappa$ coefficient was calculated to confirm that the consensus between the researchers is in the range of excellent agreement. ${ }^{19}$ Disagreements were resolved by discussion between two researchers, and a third party was consulted for unresolved disagreements.

\section{Quality assessment and data extraction}

A quality assessment was independently performed by two authors according to the Newcastle-Ottawa Scale. ${ }^{20}$ Reporting, external and internal validities, confounding bias, selection bias, and study power of each study were assessed. A study was regarded as "high quality" if it scored five or more A's out of eight.

Some data were requested by the corresponding author if the included study had no obvious data (eg, only a graph without an exact number). Data were extracted by a standardized data extraction sheet that was prepared in advance. Data included authors, citations, countries or ethnic groups, initial 6-MP dose, 6-MP dose adjustment criteria, TPMT genotypes, number of patients according to genotype, and tolerable 6-MP dose information. Statistical measures such 
as mean \pm standard deviations (SDs), median with the range of tolerable 6-MP dose, and $P$-values were extracted.

\section{Statistical analysis}

The ethnic groups were categorized as TPMT*3A alleledominant group or $* 3 C$ allele-dominant group. Weekly 6-MP doses were converted into daily doses, and dose intensities were converted into exact doses by multiplying the intensity percentage by the 6-MP start dose.

All meta-analyses were carried out by using either the Mantel-Haenszel fixed-effects model $^{21}$ or the DerSimonianLaird random-effects model, ${ }^{22}$ which depended on the heterogeneity. The degree of heterogeneity was assessed by $I^{2}$ measures (an $I^{2}>50 \%$ was considered to have substantial heterogeneity). ${ }^{23}$ Potential publication bias was detected by reviewing the funnel plot, and a sensitivity analysis was conducted.

An analysis was undertaken by using differences in mean values because tolerable 6-MP dose is continuous data. The mean and SD values from the included studies were used directly, or a substituted median for mean and range/4 for SD in the case that median and range values were presented. ${ }^{19}$ The analysis was conducted using Comprehensive MetaAnalysis version 3 (CMA 3; Biostat Inc., Englewood, NJ, USA). All statistical tests were two-sided, and the results are presented as forest plots.

\section{Results}

\section{Included studies}

A total of 397 potentially relevant articles were obtained and reviewed from a computerized search. Among them, 253 articles were excluded on the basis of publication type.
Another 137 articles were excluded as they did not fulfill the inclusion criteria (Figure 1). A total of seven studies, comprising 3,018 wild-type and 53 mutant allele pediatric ALL patients, were included (Table S1). All studies showed no risk of bias when assessing for quality using the NewcastleOttawa Scale. All of the completed trials satisfying our inclusion and exclusion criteria have been published, and there were no unpublished trials. Table 1 describes the basic information of the included studies.

Three studies from Europe (France), South America (Brazil), and the Middle East (Turkey) were categorized as the $T P M T^{*} 3 A$ allele-dominant group, and four studies from Asia (India: 2, South Korea: 1, and Taiwan: 1) were categorized as the $T P M T^{*} 3 C$ allele-dominant group. In a study, one patient with a homozygous mutant allele was included in the heterozygote group because it could not be separated. ${ }^{24}$ The $* 2 / * 2$ mutant allele carrier included in the study by $\mathrm{Kim}$ et $\mathrm{al}^{25}$ was excluded from this meta-analysis.

\section{Tolerable 6-MP dose of TPMT heterozygote in the case of an initial $6-M P$ dose $<75 \mathrm{mg} / \mathrm{m}^{2} / \mathrm{d}$}

Before conducting a pooled meta-analysis, it was observed that three of seven studies showed an insignificant difference in tolerable 6-MP dose between TPMT wild-type and heterozygote. The value of the observed $I^{2}$ was $30.7 \%$, and the heterogeneity of the included studies might not be important. Thus, the Mantel-Haenszel fixed-effects model was used to estimate the effect of TPMT genotype on the tolerable 6-MP dose. The meta-analysis results indicated that the tolerable 6-MP dose was significantly lower in the TPMT heterozygote

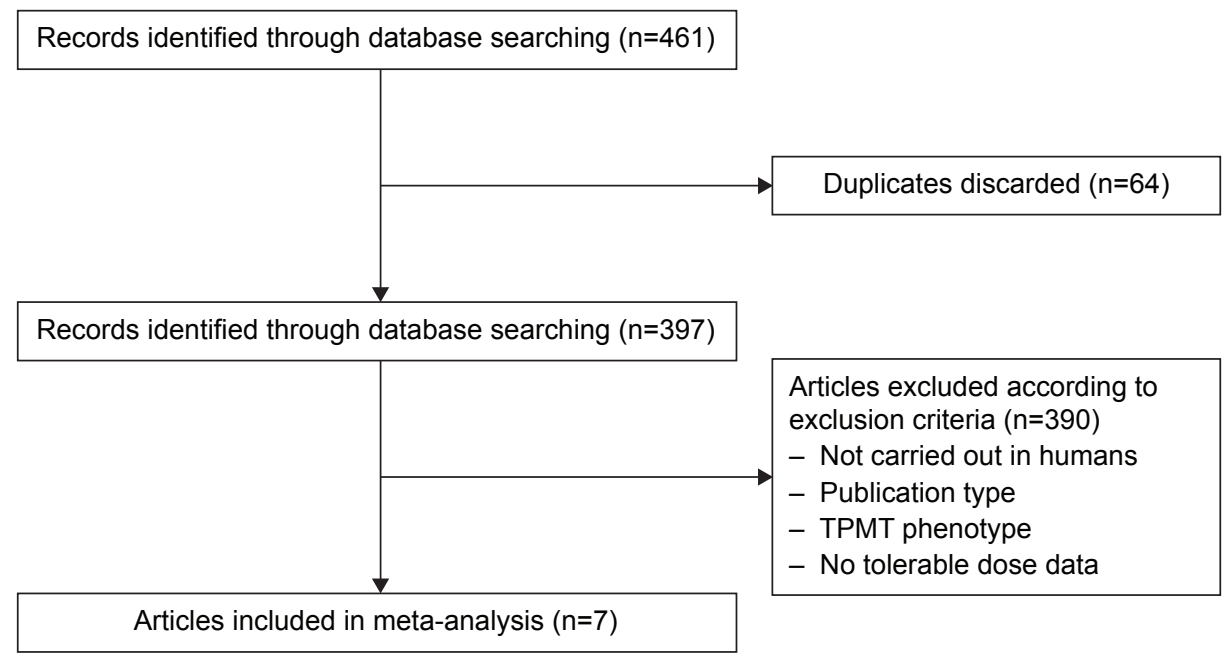

Figure I Flowchart for study selection.

Abbreviation: TPMT, thiopurine S-methyltransferase. 
Table I Characteristic of included studies

\begin{tabular}{|c|c|c|c|c|}
\hline References & Country & TPMT allele & Initial 6-MP dose & Dose adjustment \\
\hline Dervieux et $\mathrm{al}^{24}$ & France & TPMT*3A dominant & $50 \mathrm{mg} / \mathrm{m}^{2} / \mathrm{d}$ & $\begin{array}{l}\text { Target: WBC } 2,000-3,000 / \mu \mathrm{L} \\
\text { Adjustment: increase by } 25 \% \text { if two consecutive WBC } \\
>4,000 / \mu \mathrm{L} \text {, reduce by } 25 \% \text { if } \mathrm{WBC}<1,500 / \mu \mathrm{L}\end{array}$ \\
\hline Silva et $\mathrm{al}^{34}$ & Brazil & TPMT*3A dominant & $50 \mathrm{mg} / \mathrm{m}^{2} / \mathrm{d}$ & $\begin{array}{l}\text { Target: } \mathrm{WBC} 2,000-3,000 / \mu \mathrm{L}, \mathrm{ANC}>500 / \mu \mathrm{L} \text { or } \mathrm{WBC} \\
\mathrm{I}, 500-3,000 / \mu \mathrm{L}, \mathrm{ANC}>300 / \mu \mathrm{L} \text { according to } \\
\text { maintenance regimen }\end{array}$ \\
\hline Kapoor et al ${ }^{15}$ & India & TPMT*3C dominant & $50 \mathrm{mg} / \mathrm{m}^{2} / \mathrm{d}$ & Target: WBC $2,500-3,500 / \mu \mathrm{L}$, ANC $1,000-2,000 / \mu \mathrm{L}$ \\
\hline Albayrak et al ${ }^{29}$ & Turkey & $T P M T * 3 A$ dominant & $50 \mathrm{mg} / \mathrm{m}^{2} / \mathrm{d}$ & $\begin{array}{l}\text { Target: WBC } 2,000-3,000 / \mu \mathrm{L} \\
\text { Adjustment: reduce by } 50 \% \text { if } \mathrm{WBC}=1,000-2,000 / \mu \mathrm{L} \text {, } \\
\text { increase by } 150 \% \text { if } \mathrm{WBC}>3,000 / \mu \mathrm{L} \text {, withdraw if } \\
W B C<I, 000 / \mu \mathrm{L} \text { or } \mathrm{AST} / \mathrm{ALT} \geq 5 \text { times the } \mathrm{ULN} \text { or } \\
\geq \text { grade II neutropenic infection }\end{array}$ \\
\hline Kim et $\mathrm{al}^{25}$ & Korea & TPMT*3C dominant & $50 \mathrm{mg} / \mathrm{m}^{2} / \mathrm{d}$ & Adjustment: hematologic or hepatic toxicity \\
\hline Linga et $\mathrm{a}^{16}$ & India & TPMT*3C dominant & $\begin{array}{l}56.25 \mathrm{mg} / \mathrm{m}^{2} / \mathrm{d} \\
\left(75 \mathrm{mg} / \mathrm{m}^{2} / \mathrm{d} \text { for } 3 \text { weeks }\right. \\
\text { and I week skip) }\end{array}$ & Not mentioned \\
\hline Liang et $\mathrm{a}^{35}$ & Taiwan & TPMT*3C dominant & $60 \mathrm{mg} / \mathrm{m}^{2} / \mathrm{d}$ & $\begin{array}{l}\text { Target: WBC I,800-3,000/ } \mu \mathrm{L}, \text { ANC } 500-1,200 / \mu \mathrm{L} \text {, } \\
\mathrm{PLT} \geq 50,000 / \mu \mathrm{L} \\
\text { Adjustment: reduce by } 25 \% \text { if counts are low }\end{array}$ \\
\hline
\end{tabular}

Abbreviations: ALT, alanine aminotransferase; ANC, absolute neutrophil count; AST, aspartate aminotransferase; MP, mercaptopurine; PLT, platelet; TPMT, thiopurine S-methyltransferase; ULN, upper limit of normal; WBC, white blood cell.

group (difference in mean values $=11.729,95 \%$ confidence interval $[\mathrm{CI}]=7.617-15.842, P<0.001$ ) (Figure 2A).

\section{Tolerable 6-MP dose among different ethnic groups}

Among the four studies conducted in Asia, two showed a significant difference in 6-MP dose. The value of $I^{2}$ was $35.2 \%$, and the Mantel-Haenszel fixed-effects model was used. The meta-analysis resulted in a significant difference in 6-MP dose between TPMT heterozygote and wild-type (difference in mean values $=8.884,95 \% \mathrm{CI}=2.917-14.850$, $P=0.004$ ) (Figure 2B).

Three studies from the TPMT*3A allele-dominant countries showed controversial results. The included studies had heterogeneity in their features with an $I^{2}$ value of $70.2 \%$. The DerSimonian-Laird random-effects model revealed that the TPMT heterozygote received a lower 6-MP dose than the wild-type (difference in mean values $=15.324,95 \%$ $\mathrm{CI}=4.745-25.902, P=0.005$ ) (Figure 2C). The $T P M T^{*} 3 C$ allele-dominant ethnic groups needed a less reduced mean 6-MP dose ( $8.884 \mathrm{vs} 15.324 \mathrm{mg} / \mathrm{m}^{2}$ ). However, these results are not a head-to-head comparison.

\section{Discussion}

This is the first meta-analysis that compares maximum tolerable 6-MP dose between pediatric ALL patients with TPMT wild-type and heterozygous allele when considering ethnicity and receiving an initial 6-MP dose of $<75 \mathrm{mg} / \mathrm{m}^{2} / \mathrm{d}$. Although the CPIC guidelines gave an example of an initial 6-MP dose of $75 \mathrm{mg} / \mathrm{m}^{2} / \mathrm{d}$ for wild-type patients, currently most countries use $<75 \mathrm{mg} / \mathrm{m}^{2} / \mathrm{d}$ because of hematologic toxicity. ${ }^{3-5} \mathrm{We}$ found that studies conducted in the USA, the UK, Northern Europe (Denmark, Finland, Iceland, Norway, and Sweden), and Lebanon (only for lower risk patients) used a 6-MP dose of $75 \mathrm{mg} / \mathrm{m}^{2} / \mathrm{d} .{ }^{6,26-28}$ These particular studies were excluded from the meta-analysis.

The meta-analysis revealed that the 6-MP dose should further be reduced in TPMT heterozygote even with an initial 6-MP dose of $<75 \mathrm{mg} / \mathrm{m}^{2} / \mathrm{d}$. An initial 6-MP dose of $50-60 \mathrm{mg} / \mathrm{m}^{2} / \mathrm{d}$ still had severe hematologic toxicity and induced intolerance in pediatric ALL patients with the TPMT heterozygous allele. Some studies indicated that liver toxicity also partly influenced the dose reduction, ${ }^{29,25}$ although a meta-analysis of inflammatory bowel disease suggested that the TPMT polymorphisms were not associated with hepatotoxicity. ${ }^{30}$ The present metaanalysis supports the CPIC recommendation even in the case of an initial 6-MP dose of $50-60 \mathrm{mg} / \mathrm{m}^{2} / \mathrm{d}$.

This meta-analysis showed a difference in tolerable 6-MP dose between TPMT heterozygotes and wild-type among different ethnic groups. The TPMT*3A-dominant ethnic group had a more reduced tolerable 6-MP dose in comparison to the TPMT*3C-dominant ethnic group when they had a heterozygous allele. In a functional study of 23 allelic variants of the TPMT gene, which were TPMT*2 to $* 24$, the expression levels of TPMT*2, *3A,*5,*12,*14, and *22 were significantly lower than that of $T P M T^{*} 1(P<0.005)$, while TPMT $* 3 B$ and $* 3 C$ and other variants (except $T P M T^{*} 8$ and $* 18$ ) showed a nonsignificant difference with $T P M T^{*} 1 .^{31}$ Thus, the TPMT 


\section{A}

\begin{tabular}{lll} 
Study name & $\begin{array}{l}\text { Difference } \\
\text { in means }\end{array}$ & $\begin{array}{l}\text { Standard } \\
\text { error }\end{array}$ \\
\hline Dervieux et al, ${ }^{24} 2001$ & 17.000 & 7.154 \\
Silva et all ${ }^{34} 2008$ & 7.100 & 4.158 \\
Kapoor et al, ${ }^{15} 2010$ & 14.100 & 6.815 \\
Albayrak et al, ${ }^{29} 2011$ & 23.000 & 4.887 \\
Kim et al, ${ }^{25} 2012$ & 9.750 & 7.801 \\
Linga et al, ${ }^{16} 2014$ & 1.420 & 6.630 \\
Liang et al, ${ }^{35} 2015$ & 9.800 & 4.603 \\
Total & 11.729 & 2.098
\end{tabular}

Statistics for each study

Variance Lower Upper $Z$-value $P$-value

limit limit

$\begin{array}{llll}17.286 & -1.049 & 15.249 & 1.708\end{array}$

$\begin{array}{lllll}46.446 & 0.743 & 27.457 & 2.069\end{array}$

$\begin{array}{llll}23.883 & 13.422 & 32.578 & 4.706\end{array}$

$\begin{array}{llll}60.859 & -5.540 & 25.040 & 1.250\end{array}$

43.957

21.190

4.402 $\begin{array}{ll}14.415 & 0.214\end{array}$

$\begin{array}{ll}18.822 & 2.129\end{array}$

$15.842 \quad 5.590$

$\begin{array}{llll}51.174 & 2.979 & 31.021 & 2.376\end{array}$

$-11.575$

0.778

7.617

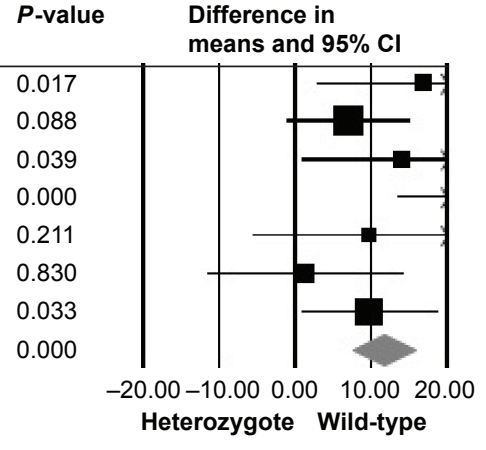

Statistics for each study

B

\begin{tabular}{|c|c|c|c|c|c|c|c|c|}
\hline Study name & $\begin{array}{l}\text { Difference } \\
\text { in means }\end{array}$ & $\begin{array}{l}\text { Standard } \\
\text { error }\end{array}$ & Variance & $\begin{array}{l}\text { Lower } \\
\text { limit }\end{array}$ & $\begin{array}{l}\text { Upper } \\
\text { limit }\end{array}$ & $Z$-value & $P$-value & $\begin{array}{l}\text { Difference in } \\
\text { means and } 95 \% \mathrm{Cl}\end{array}$ \\
\hline Kapoor et al, ${ }^{15} 2010$ & 14.100 & 6.815 & 46.446 & 0.743 & 27.457 & 2.069 & 0.039 & \\
\hline Kim et al, ${ }^{25} 2012$ & 9.750 & 7.801 & 60.859 & -5.540 & 25.040 & 1.250 & 0.211 & \\
\hline Linga et al, ${ }^{16} 2014$ & 1.420 & 6.630 & 43.957 & -11.575 & 14.415 & 0.214 & 0.830 & \\
\hline Liang et al, ${ }^{35} 2015$ & 9.800 & 4.603 & 21.190 & 0.778 & 18.822 & 2.129 & 0.033 & \\
\hline Total & 8.884 & 3.044 & 9.268 & 2.917 & 14.850 & 2.918 & 0.004 & \\
\hline
\end{tabular}

C

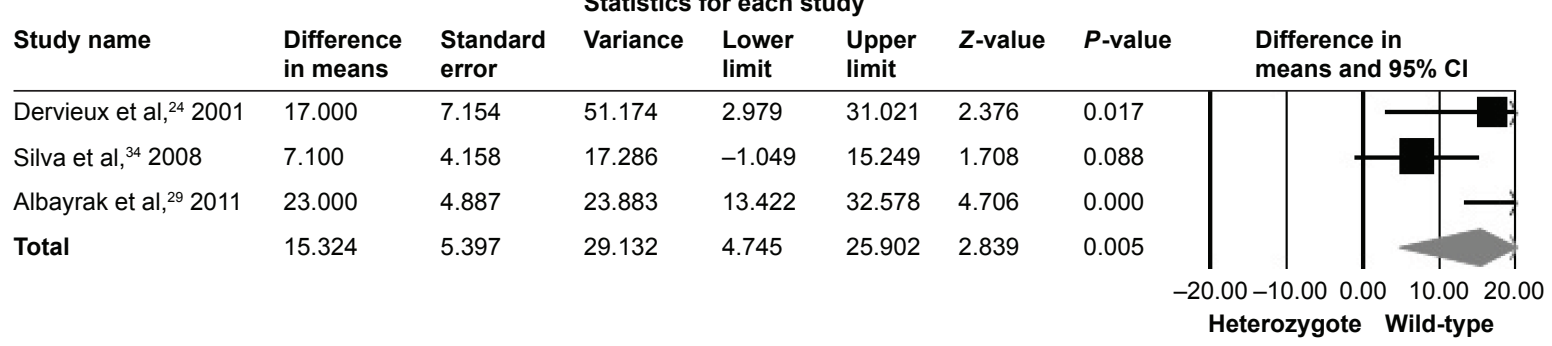

Figure 2 Forest plot of the meta-analysis: the maximum tolerable 6-MP dose of TPMT heterozygote and wild-type.

Notes: (A) Total (Mantel-Haenszel fixed-effects model); (B) TPMT*3C-dominant ethnic group (Mantel-Haenszel fixed-effects model); (C) TPMT*3A-dominant ethnic group (DerSimonian-Laird random-effects model).

Abbreviations: TPMT, thiopurine S-methyltransferase; 6-MP, 6-mercaptopurine; Cl, confidence interval.

enzyme encoded by $T P M T * 3 A$ had no activity, whereas the enzyme encoded by $T P M T^{*} 3 C$ had similar $V_{\text {max }}$ and higher $K_{\mathrm{m}}$ in comparison with the wild-type enzyme, which means decreased enzymatic activity (112 \pm 9 vs $111 \pm 6 \mathrm{nmol} / \mathrm{mg}$ protein/min and $156 \pm 12$ vs $80 \pm 8 \mu \mathrm{mol} / \mathrm{L}$, respectively). ${ }^{31}$ Alloenzyme activities of TPMT $* 3 A$ and $* 3 C$ were $1.6 \% \pm 0.6 \%$ and $17 \% \pm 1.3 \%$ of the wild-type, respectively. ${ }^{32}$

In spite of our efforts to perform a complete and thorough analysis, there are several limitations to this metaanalysis. First, differences in the characteristics of the studies might lead to heterogeneity in the results. Especially, disparate countries in the $T P M T^{*} 3 A$ allele-dominant groups (France, Brazil, and Turkey) might increase the $I^{2}$ (degree of heterogeneity) over 70\%. The DerSimonian-Laird randomeffects model was applied to the analysis, which resulted in a decrease in the $I^{2}$ value. However, a sensitivity analysis could not be carried out because of the small number of studies. Second, treatment-related advantages, such as continuous response and event-free survival of the TPMT genotype-based dosing in pediatric ALL patients, could not be evaluated because of the limited number of studies. Only one study showed that a reduced 6-MP initial dose for TPMT heterozygote might reduce secondary malignancy risk, but increase relapse risk, which is comparable to TPMT wildtype. ${ }^{33}$ Further studies are warranted to build a consensus on treatment-related advantages of TPMT genotype-based dosing. Third, a direct comparison between $T P M T * 1 / * 3 A$ and $* 1 / * 3 C$ was not possible because no studies have analyzed these particular TPMT combinations. Despite the limitations, our study can offer inspiration for a subset analysis according to the ethnicity or haplotypes.

\section{Conclusion}

The initial 6-MP dose needs to be reduced in TPMT heterozygote in comparison to wild-type, and ethnic differences might influence the tolerable 6-MP dose of TPMT heterozygote. 


\section{Acknowledgments}

This work was supported by the Seoul National University Undergraduate Research Program and the 2016 Brain Korea (BK) 21 Plus.

\section{Disclosure}

The authors report no conflicts of interest in this work.

\section{References}

1. Pui CH, Robison LL, Look AT. Acute lymphoblastic leukaemia. Lancet. 2008;371(9617):1030-1043.

2. McLeod HL, Siva C. The thiopurine S-methyltransferase gene locus implications for clinical pharmacogenomics. Pharmacogenomics. 2002;3(1):89-98.

3. Relling MV, Gardner EE, Sandborn WJ, et al. Clinical pharmacogenetics implementation consortium guidelines for thiopurine methyltransferase genotype and thiopurine dosing. Clin Pharmacol Ther. 2011;89(3):387-391.

4. Relling MV, Gardner EE, Sandborn WJ, et al. Clinical pharmacogenetics implementation consortium guidelines for thiopurine methyltransferase genotype and thiopurine dosing: 2013 update. Clin Pharmacol Ther. 2013;93(4):324-325.

5. Schmiegelow K, Nielsen SN, Frandsen TL, Nersting J. Mercaptopurine/methotrexate maintenance therapy of childhood acute lymphoblastic leukemia: clinical facts and fiction. $J$ Pediatr Hematol Oncol. 2014;36(7):503-517.

6. Relling MV, Hancock ML, Rivera GK, et al. Mercaptopurine therapy intolerance and heterozygosity at the thiopurine S-methyltransferase gene locus. J Natl Cancer Inst. 1999;91(23):2001-2008.

7. Karas-Kuzelicki N, Jazbec J, Milek M, Mlinaric-Rascan I. Heterozygosity at the TPMT gene locus, augmented by mutated MTHFR gene, predisposes to 6-MP related toxicities in childhood ALL patients. Leukemia. 2009;23(5):971-974.

8. Lennard L, Van Loon JA, Lilleyman JS, Weinshilboum RM. Thiopurine pharmacogenetics in leukemia: correlation of erythrocyte thiopurine methyltransferase activity and 6-thioguanine nucleotide concentrations. Clin Pharmacol Ther. 1987;41(1):18-25.

9. Black AJ, McLeod HL, Capell HA, et al. Thiopurine methyltransferase genotype predicts therapy-limiting severe toxicity from azathioprine. Ann Intern Med. 1998;129(9):716-718.

10. Colombel JF, Ferrari N, Debuysere H, et al. Genotypic analysis of thiopurine S-methyltransferase in patients with Crohn's disease and severe myelosuppression during azathioprine therapy. Gastroenterology. 2000;118(6):1025-1030.

11. Evans WE, Hon YY, Bomgaars L, et al. Preponderance of thiopurine S-methyltransferase deficiency and heterozygosity among patients intolerant to mercaptopurine or azathioprine. J Clin Oncol. 2001;19(8):2293-2301.

12. Colleoni L, Kapetis D, Maggi L, et al. A new thiopurine s-methyltransferase haplotype associated with intolerance to azathioprine. $J$ Clin Pharmacol. 2013;53(1):67-74.

13. Kubota T, Chiba K. Frequencies of thiopurine S-methyltransferase mutant alleles (TPMT*2, *3A, *3B and *3C) in 151 healthy Japanese subjects and the inheritance of TPMT*3C in the family of a propositus. Br J Clin Pharmacol. 2001;51(5):475-477.

14. Yang JJ, Landier W, Yang W, et al. Inherited NUDT15 variant is a genetic determinant of mercaptopurine intolerance in children with acute lymphoblastic leukemia. J Clin Oncol. 2015;33(11):1235-1242.

15. Kapoor G, Sinha R, Naithani R, Chandgothia M. Thiopurine S-methyltransferase gene polymorphism and 6-mercaptopurine dose intensity in Indian children with acute lymphoblastic leukemia. Leuk Res. 2010;34(8):1023-1026.

16. Linga VG, Patchva DB, Mallavarapu KM, et al. Thiopurine methyltransferase polymorphisms in children with acute lymphoblastic leukemia. Indian J Med Paediatr Oncol. 2014;35(4):276-280.
17. Moher D, Liberati A, Tetzlaff J, Altman DG, The PRISMA Group. Preferred reporting items for systematic reviews and meta-analyses: the PRISMA statement. PLoS Med. 2009;6(7):e1000097.

18. Chan AW. Out of sight but not out of mind: how to search for unpublished clinical trial evidence. BMJ. 2012;344:d8013.

19. Higgins JPT, Green S. Cochrane Handbook for Systematic Reviews of Interventions. Version 5.1.0 [updated March 2011]. The Cochrane Colaboration, 2011. Available from: http://handbook.cochrane.org

20. Wells GA, Shea B, O'Connell D, et al. The Newcastle-Ottawa Scale (NOS) for assessing the quality of nonrandomized studies in metaanalyses. Available from: http://www.ohri.ca/programs/clinical_epidemiology/oxford.asp. Accessed September 29, 2016.

21. Mantel N, Haenszel W. Statistical aspects of the analysis of data from retrospective studies of disease. J Natl Cancer Inst. 1959;22(4): 719-748.

22. DerSimonian R, Laird N. Meta-analysis in clinical trials. Control Clin Trials. 1986;7(3):177-188

23. Collaboration TC. Cochrane Handbook for Systematic Reviews of Interventions, 2011. Available from: http://handbook.cochrane.org/ chapter_9/9_5_2_identifying_and_measuring_heterogeneity.htm. Accessed April 18, 2016.

24. Dervieux T, Medard Y, Verpillat P, et al. Possible implication of thiopurine S-methyltransferase in occurrence of infectious episodes during maintenance therapy for childhood lymphoblastic leukemia with mercaptopurine. Leukemia. 2001;15(11):1706-1712.

25. Kim H, Kang HJ, Kim HJ, et al. Pharmacogenetic analysis of pediatric patients with acute lymphoblastic leukemia: a possible association between survival rate and ITPA polymorphism. PLoS One. 2012;7(9):e45558.

26. Lennard L, Cartwright CS, Wade R, Vora A. Thiopurine methyltransferase and treatment outcome in the UK acute lymphoblastic leukaemia trial ALL2003. Br J Haematol. 2015;170(4):550-558.

27. Lennard L, Cartwright CS, Wade R, Vora A. Thiopurine dose intensity and treatment outcome in childhood lymphoblastic leukaemia: the influence of thiopurine methyltransferase pharmacogenetics. Br J Haematol. 2015;169(2):228-240.

28. Schmiegelow K, Forestier E, Kristinsson J, et al. Thiopurine methyltransferase activity is related to the risk of relapse of childhood acute lymphoblastic leukemia: results from the NOPHO ALL-92 study. Leukemia. 2009;23(3):557-564.

29. Albayrak M, Konyssova U, Kaya Z, et al. Thiopurine methyltransferase polymorphisms and mercaptopurine tolerance in Turkish children with acute lymphoblastic leukemia. Cancer Chemother Pharmacol. 2011;68(5):1155-1159.

30. Donnan JR, Ungar WJ, Mathews M, Rahman P. Systematic review of thiopurine methyltransferase genotype and enzymatic testing strategies. Ther Drug Monit. 2011;33(2):192-199.

31. Ujiie S, Sasaki T, Mizugaki M, Ishikawa M, Hiratsuka M. Functional characterization of 23 allelic variants of thiopurine S-methyltransferase gene (TPMT*2 - *24). Pharmacogenet Genomics. 2008;18(10): 887-893.

32. Salavaggione OE, Wang L, Wiepert M, Yee VC, Weinshilboum RM. Thiopurine S-methyltransferase pharmacogenetics: variant allele functional and comparative genomics. Pharmacogenet Genomics. 2005;15(11):801-815.

33. Levinsen M, Rotevatn EO, Rosthoj S, et al. Pharmacogenetically based dosing of thiopurines in childhood acute lymphoblastic leukemia: influence on cure rates and risk of second cancer. Pediatr Blood Cancer. 2014;61(5):797-802.

34. Silva MR, De Oliveira BM, Viana MB, Murao M, Romanha AJ. Thiopurine S-Methyltransferase (TPMT) gene polymorphism in Brazilian children with acute lymphoblastic leukemia: Association with clinical and laboratory data. Therapeutic Drug Monitoring. 2008;30(6): 700-704.

35. Liang DC, Yang CP, Liu HC, et al. NUDT15 gene polymorphism related to mercaptopurine intolerance in Taiwan Chinese children with acute lymphoblastic leukemia. Pharmacogenomics J. Epub 2015. 


\section{Supplementary material}

Table SI Demographics of studied population

\begin{tabular}{|c|c|c|c|}
\hline References & Sex (male/female) & Age in years & Haplotype distribution (n) \\
\hline \multicolumn{4}{|l|}{ Dervieux et al,' 200I } \\
\hline All patients $(n=78)$ & $47 / 31$ & $5.5 \pm 3.1($ mean $\pm S D)$ & $\begin{array}{l}* I / * I(70), * I / * 2(2), * I / * 3 A(4), * I / * 3 C(I), \\
* 3 C / * 3 C(I)\end{array}$ \\
\hline \multicolumn{4}{|l|}{ Silva et al, ${ }^{2} 2008$} \\
\hline All patients $(n=116)$ & $58 / 58$ & $<$ I yr: $n=I, I-9.9$ yr: $n=95, \geq 10$ yr: $n=20$ & $* I / * I(I 04), * I / * 2(1), * I / * 3 A(9), * I / * 3 C$ (2) \\
\hline \multicolumn{4}{|l|}{ Kapoor et al, ${ }^{3} 2010$} \\
\hline Wild-types $(n=64)$ & $49 / 15$ & $\leq 9 \mathrm{yr}: \mathrm{n}=43,>9 \mathrm{yr}: \mathrm{n}=21$ & $* I / * I(64)$ \\
\hline Variants $(n=7)$ & $6 / 1$ & $\leq 9$ yr: $n=7,>9$ yr: $n=0$ & $* I / * 2(3), * I / * 3 A(I), * I / * 3 C(3)$ \\
\hline \multicolumn{4}{|l|}{ Albayrak et al, ${ }^{4} 20 \mathrm{II}$} \\
\hline Wild-types $(n=47)$ & $31 / 16$ & $7.2 \pm 4.7($ mean $\pm S D)$ & $* I / * I(47)$ \\
\hline Variants $(n=4)$ & $2 / 2$ & $8.2 \pm 4.6($ mean $\pm S D)$ & $* I / * 3 \mathrm{~A}(3), * I / * 3 C(1)$ \\
\hline \multicolumn{4}{|l|}{ Kim et al, ${ }^{5} 2012$} \\
\hline All patients $(n=100)$ & $57 / 43$ & $5.2(1.4-16)($ median [range]) & $* I / * I(93), * 2 / * 2(I), * I / * 3 A(I), * I / * 3 C(5)$ \\
\hline \multicolumn{4}{|l|}{ Linga et al, ${ }^{6} 2014$} \\
\hline All patients $(n=72)$ & $57 / 15$ & $9(2-18)$ (median [range]) & 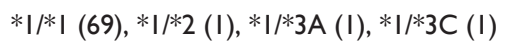 \\
\hline \multicolumn{4}{|l|}{ Liang et al,7 2015} \\
\hline All patients $(n=3 \mid 0)$ & NA & NA & $* I / * I(298), I / * 3 A$ or $* 3 C(12)$ \\
\hline
\end{tabular}

Abbreviations: NA, not available; SD, standard deviation; yr, years.

\section{References}

1. Dervieux T, Medard Y, Verpillat P, et al. Possible implication of thiopurine S-methyltransferase in occurrence of infectious episodes during maintenance therapy for childhood lymphoblastic leukemia with mercaptopurine. Leukemia. 2001;15(11):1706-1712.

2. Silva MR, De Oliveira BM, Viana MB, Murao M, Romanha AJ. Thiopurine S-Methyltransferase (TPMT) gene polymorphism in Brazilian children with acute lymphoblastic leukemia: Association with clinical and laboratory data. Therapeutic Drug Monitoring. 2008;30(6): 700-704.

3. Kapoor G, Sinha R, Naithani R, Chandgothia M. Thiopurine S-methyltransferase gene polymorphism and 6-mercaptopurine dose intensity in Indian children with acute lymphoblastic leukemia. Leuk Res. 2010; 34(8):1023-1026.
4. Albayrak M, Konyssova U, Kaya Z, et al. Thiopurine methyltransferase polymorphisms and mercaptopurine tolerance in Turkish children with acute lymphoblastic leukemia. Cancer Chemother Pharmacol. 2011; 68(5):1155-1159.

5. Kim H, Kang HJ, Kim HJ, et al. Pharmacogenetic analysis of pediatric patients with acute lymphoblastic leukemia: a possible association between survival rate and ITPA polymorphism. PLoS One. 2012;7(9): e45558.

6. Linga VG, Patchva DB, Mallavarapu KM, et al. Thiopurine methyltransferase polymorphisms in children with acute lymphoblastic leukemia Indian J Med Paediatr Oncol. 2014;35(4):276-280.

7. Liang DC, Yang CP, Liu HC, et al. NUDT15 gene polymorphism related to mercaptopurine intolerance in Taiwan Chinese children with acute lymphoblastic leukemia. Pharmacogenomics J. Epub 2015.
OncoTargets and Therapy

\section{Publish your work in this journal}

OncoTargets and Therapy is an international, peer-reviewed, open access journal focusing on the pathological basis of all cancers, potential targets for therapy and treatment protocols employed to improve the management of cancer patients. The journal also focuses on the impact of management programs and new therapeutic agents and protocols on

\section{Dovepress}

patient perspectives such as quality of life, adherence and satisfaction. The manuscript management system is completely online and includes a very quick and fair peer-review system, which is all easy to use. Visit http://www.dovepress.com/testimonials.php to read real quotes from published authors. 